\title{
Application of catalysts in the treatment of selected waste chloroorganic compounds
}

\author{
Andrzej Żarczyński, Marcin Zaborowski, Tadeusz Paryjczak, Zbigniew Gorzka, Marek Kaźmierczak
}

Technical University of Łódź, Institute of General end Ecological Chemistry, ul. Żeromskiego 116, 90-924 Łódż, Poland, e-mail: andrzejzarcz@o2.pl, tel. (+48 42) 631-31-18

\begin{abstract}
Tetrachloromethane (TCM) and 1,1,2,2-tetrachloroethane (TChE) were oxidized in the temperature range from 300 to $600^{\circ} \mathrm{C}$ and at contact time of $0.36 \mathrm{~s}$. The following catalysts were applied during the process: the granular one - platinum $(0.12 \%)$ at the $\mathrm{TiO}_{2}-\mathrm{SiO}_{2}$ carrier, platinum $\mathrm{ZChO}-80(0.15 \%)$ at $\gamma-\mathrm{Al}_{2} \mathrm{O}_{3}$ carrier, palladium (1\%) at $\gamma-\mathrm{Al}_{2} \mathrm{O}_{3}$ carrier and monolithic platinum-rhodium catalyst $(\mathrm{Pt}-0.09 \%$ and $\mathrm{Rh}-0.04 \%)$ at the cordierite carrier.

The substrates were oxidized in the presence of the above mentioned catalysts with various efficiencies depending on the molecular structure and the type of the catalyst. Palladium contact appeared to be the most active among the others. In the presence of this catalyst, total oxidation of TCM and TChE proceeded at the temperature of 425 and $500^{\circ} \mathrm{C}$, respectively. The content of $\mathrm{PCDD} / \mathrm{Fs}$ in gaseous products obtained during the oxidation of both substrates, was significantly lower than the admissible value of the toxicity equivalent $\left(0.1 \mathrm{ng} \mathrm{TEQ} / \mathrm{m}^{3}\right)$.
\end{abstract}

Keywords: thermocatalytic oxidation, tetrachloromethane, 1,1,2,2-tetrachloroethane, chloroorganic wastes, dioxins emision.

Presented at VII Conference Wasteless Technologies and Waste Management in Chemical Industry and Agriculture, Międzyzdroje, 12 - 15 June, 2007.

\section{INTRODUCTION}

Liquid and gaseous chloroorganic wastes, which are produced in the amount of 5,000 ton in Poland yearly, contain among others chlorine derivatives of methane, ethane, propane and phenol. They are utilized on industrial scale by combustion at the temperature of about $1350^{\circ} \mathrm{C}^{\mathbf{1}, 2}$. The application of proper catalysts enables a decrease in the temperature to $300-600^{\circ} \mathrm{C}$ during their total oxidation without a harmful effect on the environment and a simultaneous decrease in process costs. This is proved by the results of the investigation carried out in various scientific centers ${ }^{3-14}$.

The previous investigation carried out in our Institute, included among others the oxidation of propylene chlorohydrin, 1,2-dichloropropane, tetrachloromethane (TCM), 1,1,2,2- tetrachloroethane (TChE), organic compounds of sulphur and nitrogen (thiazole and diphenylosulfone) with the application of catalysts. Granular contacts containing platinum deposited at $\gamma-\mathrm{Al}_{2} \mathrm{O}_{3}$ and pressed copper and zinc oxides were used in the investigation. In the case of the selected substrates, monolithic

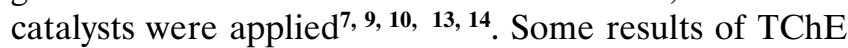
oxidation with the application of monolithic catalysts containing platinum (and rhodium in one case) at intermediate layers with $\gamma-\mathrm{Al}_{2} \mathrm{O}_{3}, \mathrm{ZrO}_{2}$ and $\mathrm{TiO}_{2}$ deposited at cordierite, were published earlier' ${ }^{9}$. Then, the usability of the monolithic catalysts containing $\mathrm{Pt}(0.09 \%)$ and $\mathrm{Rh}$ $(0.04 \%)$ at the intermediate layer with $\gamma-\mathrm{Al}_{2} \mathrm{O}_{3}$ deposited at cordierite, was proved in the process of TChE utilization. At present, the investigation area was extended and included TCM oxidation and other granular catalysts. The results of the investigation were compared with the results of substrates oxidation with the application of the above mentioned monolithic catalyst.

\section{EXPERIMENTAL}

The subject of investigation was TCM (400-500 mg/ $\left.\mathrm{m}^{3}\right)$ and TChE $\left(850-1000 \mathrm{mg} / \mathrm{m}^{3}\right)$ in a mixture with air $(200-215 \mathrm{l} / \mathrm{h})$ and water vapour $(32.5 \mathrm{~g} / \mathrm{h})$. These conditions guaranteed the contact time of $0.36 \mathrm{~s}$. First, the mixture was heated in an evaporator to $160^{\circ} \mathrm{C}$ and next pumped through a layer of a granular or monolithic catalyst. The following catalysts were applied in the investigation:

- platinum (Pt-Ti) containing $0.12 \% \mathrm{Pt}$ at a carrier with $\mathrm{TiO}_{2}-\mathrm{SiO}_{2}$, prepared in the Institute of Chemistry and Technology of Petroleum and Coal, Wrocław University of Technology;

- platinum (ZChO-80) containing $0.15 \% \mathrm{Pt}$ at a carrier with $\gamma-\mathrm{Al}_{2} \mathrm{O}_{3}$, prepared in the Institute of Environmental Engineering, Wrocław University of Technology;

- palladium (Pd) containing 1\% $\mathrm{Pd}$ at a carrier with $\gamma-\mathrm{Al}_{2} \mathrm{O}_{3}$ prepared, in Catalyst Company Ltd., Kraków,

- monolithic platinum-rhodium catalyst (Pt-Rh) containing $0.09 \% \mathrm{Pt}$ and $0.04 \% \mathrm{Rh}$ at an intermediate layer with $\gamma-\mathrm{Al}_{2} \mathrm{O}_{3}$ deposited at a cordierite carrier, prepared in JMJ Catalyst Factory Puchalski and Krawczyk, Nowe Skalmierzyce, 13.

The experiments were carried out in the temperature range from 300 to $600^{\circ} \mathrm{C}$. The aim of the experiments was the determination of optimum parameters during the total catalytic oxidation of the substrates and the determination of polychlorinated dibenzo-p-dioxins and polychlorinated dibenzofuranes $(\mathrm{PCDD} / \mathrm{Fs})$ content in the gaseous reaction products. The cooled down combustion gases and the aqueous condensate were the reaction products. The final products, i.e. hydrogen chloride, water vapour and carbon dioxide, were obtained. The concentration of chloride ions was analyzed in the condensate. Other analyses included the determination of concentration of the products obtained during the incomplete substrates oxidation, e.g. 
formaldehyde, chlorine, carbon monoxide, total organic carbon (TOC) and PCDD/Fs. Combustion gases samples with the volume of $10 \mathrm{~m}^{3}$ were sampled at the temperature of $550^{\circ} \mathrm{C}$ and analyzed in order to determine the dioxins content. Determinations of PCDD/Fs were carried out in The Environmental Protection Laboratory of Pulp \& Paper Research Institute in Łódź, according to the European Standard EN-1948 ${ }^{15}$.

\section{RESULTS AND DISCUSSION}

The results of the experiments are presented in Figs. $1-5$ and Table 1 .

Conversion dependence of TCM oxidation on the process temperature in the range from 300 to $550^{\circ} \mathrm{C}$ with the application of granular $\mathrm{Pd}$ and $\mathrm{ZChO}-80$ catalysts and monolithic Pt-Rh catalyst are presented in Fig. 1. A dependence of TChE conversion on the reaction temperature in the range from 300 to $600^{\circ} \mathrm{C}$ with the application of four tested catalysts is presented in Fig. 2.

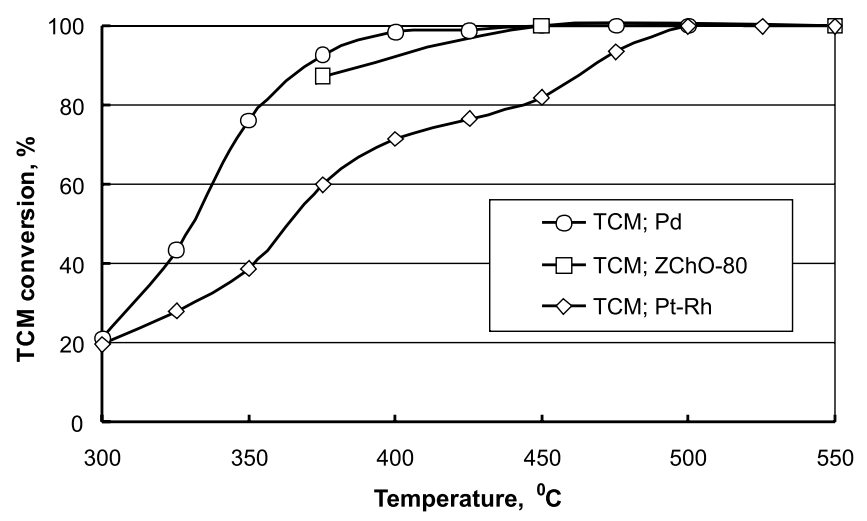

Figure 1. Dependence of the TCM conversion on the reaction temperature

Figs 1 and 2 show that TCM is oxidized easier than TChE. Total oxidation of the first substrate was achieved at the temperature of $425^{\circ} \mathrm{C}$ with the application of the palladium $(\mathrm{Pd})$ catalyst, in $450^{\circ} \mathrm{C}$ with the $\mathrm{ZChO}$ catalyst and at $525^{\circ} \mathrm{C}$ - with the monolithic one. The curves in Fig. 2 prove that the total oxidation of TChE proceeded at the temperature of 500 and $550^{\circ} \mathrm{C}$ in the presence of granular and Pt-Rh catalyst, respectively. The activity of the granular catalysts depended mainly on the content of active components at carriers. An activity comparison of $\mathrm{Pt}-\mathrm{Rh}$, platinum-zirconium and platinum-titanium monoliths used in the TChE oxidation is described in the paper'.

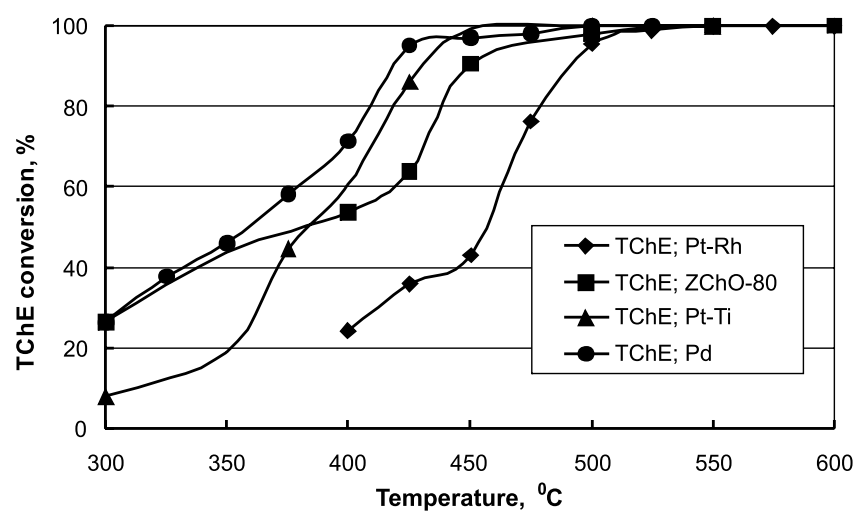

Figure 2. Dependence of the TChE conversion on the reaction temperature
A dependence of TOC values in the condensate obtained during the TCM and TChE oxidation is presented in Fig. 3. The results of the TOC analyses did not exceed the value of $9 \mathrm{mgC} / \mathrm{l}$ and in most experiments were at the level of $1-3 \mathrm{mgC} / \mathrm{l}$. This maximum value was achieved during the TChE oxidation with the application of the platinum ZChO- 80 catalyst at the temperature of $350^{\circ} \mathrm{C}^{10}$. The TOC value, which does not exceed $3 \mathrm{mgC} / \mathrm{l}$, proves the presence of soluble organic compounds in the condensate, i.e. the products of incomplete substrate oxidation. For example - the liquid and gaseous products of organic compounds oxidation contain also formaldehyde $\mathrm{e}^{\mathbf{7 , 9 , 1 0 , 1 3 , 1 4}}$. Carbon contained in the formaldehyde molecules, has significant contribution in the TOC value determined in the condensate. Carbon monoxide is the simplest product of the incomplete oxidation of organic compounds. The presence of carbon monoxide in the combustion gases shows that the reaction temperature is too low, the contact time is too short and the catalyst is not properly chosen or deactivated.

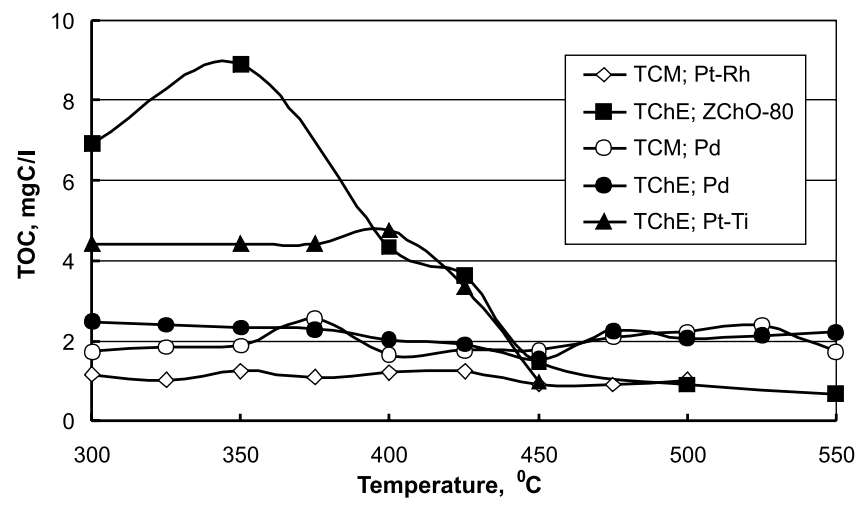

Figure 3. Dependence of the TOC value in a condensate on the temperature of the TCM and TChE oxidation

Fig. 4. presents the dependence of chloride ions concentration in the condensate on the temperature in the range from 300 to $600^{\circ}$ in the oxidation of TCM and TChE with the application of the catalysts. The concentration of chloride ions is stabilized at temperatures higher than the temperature at which the complete oxidation of the substrate is achieved with the application of the tested catalyst. During the oxidation of TCM with Pd catalyst at $450^{\circ} \mathrm{C}$ and with the Pt-Rh catalyst at $500^{\circ} \mathrm{C}$, the chloride ions concentration was almost constant and totaled 3300 $-4000 \mathrm{mg} / \mathrm{l}$. In the TChE oxidation at temperatures higher than $500^{\circ} \mathrm{C}$, the chloride ions concentration was in the range from 5200 to $5900 \mathrm{mg} / \mathrm{l}$.

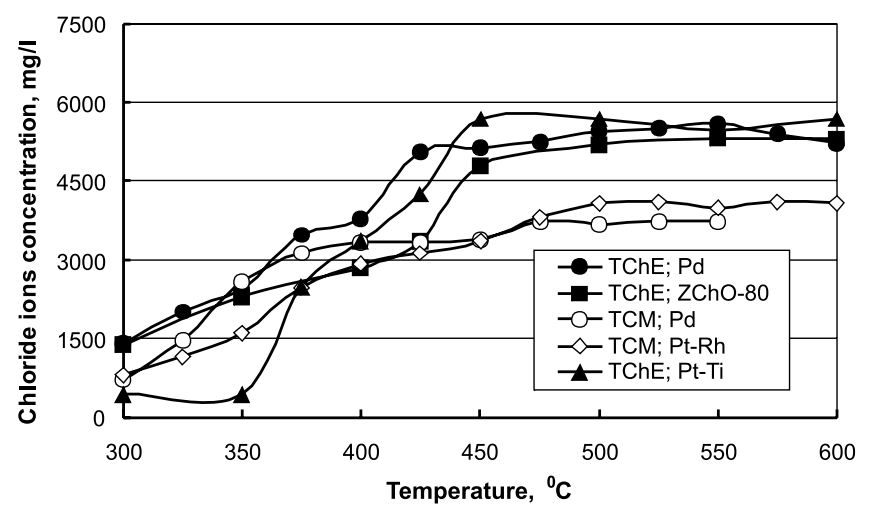

Figure 4. Dependence of chloride ions concentration in a condensate on the temperature of the TCM and TChE oxidation 
Fig. 5. presents the dependence of chlorine concentration in combustion gases on the temperature of TCM and TChE oxidation. The presence of chlorine was found in the combustion gases although water vapour was dosed in the all tested temperature ranges and with the application of all catalysts. The chlorine concentration achieved maximum values at the level of several $\mathrm{mg} / \mathrm{m}^{3}$ in the temperature range from 425 to $475^{\circ} \mathrm{C}$, depending on the catalyst activity and the substrate type. Chlorine is the reactive product of dechlorination and oxidation of chloroorganic compounds. It may be formed also in Deacon's reaction as the result of hydrogen chloride oxidation.

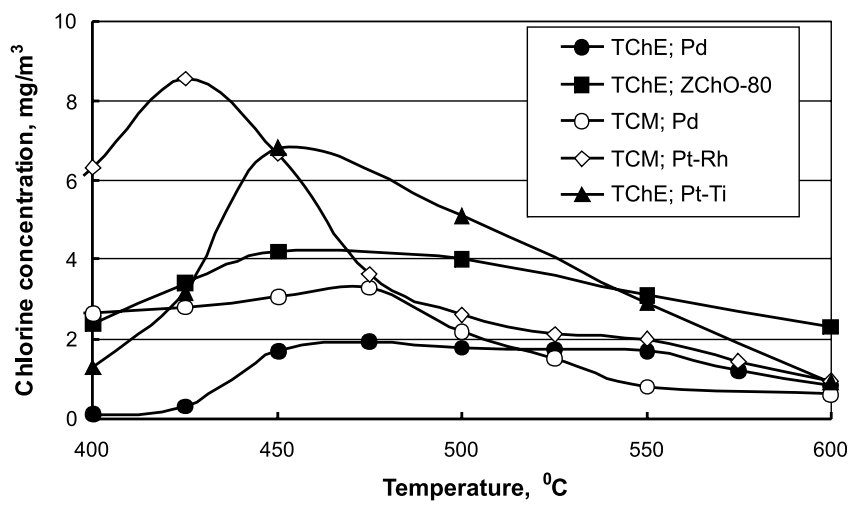

Figure 5. Dependence of chlorine concentration in combustion gases on the temperature of the TCM and TChE oxidation

No decrease in the activity of all the tested catalysts was observed.

Table 1 presents the content of $\mathrm{PCDD} / \mathrm{Fs}$ in combustion gases sampled during the TCM and TChE oxidation in $450^{\circ} \mathrm{C}$ with the application of the granular catalysts and at $550^{\circ} \mathrm{C}$ with the presence of the monolithic catalyst. The values of the toxicity equivalent (TEQ) were calculated as the maximum content of PCDD/Fs taking into account the lower limit of determination of the 17 analyzed congeners, i.e. congeners with chlorine atoms bounded with carbon atoms in positions 2,3,7,8, which are regarded as the most toxic and must be determined according to law regulations ${ }^{16,17}$. The samples of combustion gases contained several congeners of $\mathrm{PCDD} / \mathrm{Fs}$, but no presence of 2,3,7,8-tetrachlorodibenzo-p-dioxin was found. Congeners from $\mathrm{P}_{5} \mathrm{CDFs}, \mathrm{H}_{6} \mathrm{CDDs}$ and $\mathrm{H}_{6} \mathrm{CDFs}$ groups, formed during the TCM and TChE oxidation with the application of Pt-Ti and during the TChE oxidation with ZChO-80, were especially numerous in combustion gases samples. Toxicity equivalents in the combustion gases samples were significantly lower than the admissible value of $0,1 \mathrm{ngTEQ} /$ $\mathrm{m}^{3}$, except for the sample obtained during the TChE oxidation with the Pt-Ti catalyst. In this case, the toxicity equivalent was $0.088 \mathrm{ngTEQ} / \mathrm{m}^{3}$. Concentrations of dioxins were especially low in the samples obtained during the substrates oxidation with the Pd catalyst. Toxicity equivalents in combustion gases samples prove that the application of the catalysts efficiently counteracted PCDD/ Fs formation during the oxidation of the substrates and other compounds, especially propylene chlorohydrin, described in the previous paper ${ }^{14}$.

The results of the investigation show the significant activity of the tested catalyst in the reactions of TCM and TChE oxidation. The catalyst, especially Pd and Pt-Rh, can be applied on an enlarged scale. Taking into consideration the results of the previous investigation, it can be assumed that utilization and treatment processes of various chlorinated hydrocarbons can be efficiently carried out in at the temperature of 500 and $550^{\circ} \mathrm{C}$ with the application of the granular Pd and monolithic catalyst, respectively. That means the possibility of a decrease in a treatment temperature of methane and ethane in comparison with the currently applied high-temperature combustion in the temperature range from 1300 to $1350^{\circ} \mathrm{C}$.

\section{CONCLUSION}

This paper describes the problems concerning an activity of three granular and one monolithic catalysts in the oxidation of methane and ethane tetrachloroderivatives. Two granular contacts contained platinum $(0.12$ and $0.15 \%$, respectively) at carriers with $\mathrm{TiO}_{2}-\mathrm{SiO}_{2}$ and $\gamma-\mathrm{Al}_{2} \mathrm{O}_{3}(\mathrm{ZChO}-80)$. The third contact contained palla-

Table 1. The content of PCDD/Fs in combustion gases sampled during the TCM and TChE oxidation

\begin{tabular}{|c|c|c|c|}
\hline \multirow{2}{*}{$\begin{array}{l}\text { Oxidized compound; catalyst; } \\
\text { temperature }\end{array}$} & $\begin{array}{c}2,3,7,8-P C D D s \\
\text { congeners }\end{array}$ & $\begin{array}{c}2,3,7,8-P C D F s \\
\text { congeners }\end{array}$ & $\begin{array}{c}\mathrm{PCDD} / \mathrm{Fs} \\
\text { total concentration }\end{array}$ \\
\hline & name & Name & $\mathrm{ngTEQ} / \mathrm{m}^{3}$ \\
\hline $\begin{array}{l}\mathrm{TCM} ; \mathrm{Pd} ; \\
\mathrm{T}=450{ }^{\circ} \mathrm{C}\end{array}$ & not detected & $2,3,7,8-\mathrm{TCDF}$ & $<0.0111$ \\
\hline $\begin{array}{l}\text { TCM; } \\
\text { Pt-Rh; } \\
\text { T = } 550{ }^{\circ} \mathrm{C}\end{array}$ & not detected & $\begin{array}{c}\text { 2,3,7,8-TCDF } \\
1,2,3,4,7,8-\mathrm{P}_{6} \mathrm{CDF} \\
1,2,3,6,7,8-\mathrm{P}_{6} \mathrm{CDF} \\
1,2,3,4,6,7,8-\mathrm{H}_{7} \mathrm{CDF}\end{array}$ & $<0.0154$ \\
\hline $\begin{array}{l}\text { TChE; } \\
\text { ZChO-80; } \\
\text { T=450 }{ }^{\circ} \mathrm{C}^{10}\end{array}$ & $1,2,3,7,8,9-\mathrm{H}_{6} \mathrm{CDD}$ & $\begin{array}{c}\text { 2,3,7,8-TCDF } \\
1,2,3,7,8-\mathrm{P}_{5} \mathrm{CDF} \\
2,3,4,7,8-\mathrm{P}_{5} \mathrm{CDF}\end{array}$ & $<0.0151$ \\
\hline $\begin{array}{l}\text { TChE; } \\
\text { Pt-Ti; } \\
\mathrm{T}=450{ }^{0} \mathrm{C}^{10,14}\end{array}$ & $\begin{array}{c}1,2,3,4,7,8-\mathrm{H}_{6} \mathrm{CDD} \\
1,2,3,6,7,8-\mathrm{H}_{6} \mathrm{CDD} \\
1,2,3,7,8,9-\mathrm{H}_{6} \mathrm{CDD} \\
1,2,3,4,6,7,8-\mathrm{H}_{7} \mathrm{CDD}\end{array}$ & $\begin{array}{c}1,2,3,7,8-\mathrm{P}_{5} \mathrm{CDF} \\
2,3,4,7,8-\mathrm{P}_{5} \mathrm{CDF} \\
1,2,3,4,7,8-\mathrm{H}_{6} \mathrm{CDF} \\
1,2,3,6,7,8-\mathrm{H}_{6} \mathrm{CDF} \\
1,2,3,7,8,9-\mathrm{H}_{6} \mathrm{CDF} \\
1,2,3,4,6,7,8-\mathrm{H}_{7} \mathrm{CDF} \\
1,2,3,4,7,8,9-\mathrm{H}_{7} \mathrm{CDF}\end{array}$ & $<0.088$ \\
\hline $\begin{array}{l}\text { TChE; Pd; } \\
\mathrm{T}=450{ }^{\circ} \mathrm{C}\end{array}$ & not detected & not detected & $<0.0087$ \\
\hline $\begin{array}{l}\text { TChE; Pt-Rh; } \\
\mathrm{T}=550{ }^{0} \mathrm{C}^{9,14}\end{array}$ & not detected & $2,3,7,8$-TCDF & $<0.0035$ \\
\hline
\end{tabular}


dium $(1 \%)$ at the carrier with $\gamma-\mathrm{Al}_{2} \mathrm{O}_{3}$. The monolithic catalyst $(\mathrm{Pt}-\mathrm{Rh})$ contained platinum $(0.09 \%)$ and rhodium $(0.04 \%)$ at the intermediate layer with $\gamma-\mathrm{Al}_{2} \mathrm{O}_{3}$ deposited at the cordierite. Special attention was paid to an effect of the temperature in the oxidation of the substrate in the gaseous phase with the mixture of oxygen excess from air and water vapour. In the presence of granular contacts, the complete oxidation of the substrates was achieved in the temperature range from 425 to $500^{\circ} \mathrm{C}$. The TCM and TChE substrates were completely oxidized with the application of Pt-Rh catalyst at the temperature of 500 and $550^{\circ} \mathrm{C}$, respectively. The investigation results show that the catalysts activity depends mainly on the type and content of active components as well as on the catalyst structure. The investigation with the application of $\mathrm{Pd}$ and Pt-Rh catalysts proved that TCM was easier oxidized than TChE.

Moreover, the content of $\mathrm{PCDD} / \mathrm{Fs}$ in the combustion gases was much lower than the value of $0.1 \mathrm{ngTEQ} / \mathrm{m}^{3}$, which is admissible in the countries of European Union. The TChE oxidation in the presence of Pt-Ti catalyst was the exception. No deactivation of the catalysts was observed during the oxidation of TChE or TCM as well as other previously investigated organic chlorine compounds including chlorohydrin ${ }^{14}$. The investigation results prove the possibility of the decrease in temperature to $550^{\circ} \mathrm{C}$ during the waste organic chlorine compounds treatment in the catalytic process carried out with the application of $\mathrm{Pt}-\mathrm{Rh}$ catalyst, in comparison with the currently applied high-temperature combustion $\left(1300-1350^{\circ} \mathrm{C}\right)$.

\section{ACKNOWLEGMENTS}

This research is supported by the Polish State Committee for Scientific Research in 2004 - 2007, grant No. 3 T09B 08327.

\section{LITERATURE CITED}

(1) Przondo J., Rogala J.: Przemysłowa instalacja spalania ciekłych odpadów chloroorganicznych w Z. Ch. „Rokita” S. A., Przem. Chem., 1996, 75, 98.

(2) Lewandowski G., Milchert E., Doroczyński A.: Spalanie odpadowych chloropochodnych organicznych odzyskiem chlorowodoru, Przem. Chem., 2005, 84, 516.

(3) Agarval S. K., Spivey J. J., Butt J. B.: Catalyst deactivation during deep oxidation of chlorocarbons, Appl. Catal. A: General, 1992, 82, 259.

(4) Cybulski A., Moulijn J. A.: Monoliths in heterogenous catalysis, Catal. Rev.-Sci. Eng., 1994, 36, 179.

(5) Lester G. R.: Catalytic destruction of hazardous halogenated organic chemicals, Catal. Today, 1999, 53, 407.

(6) Corella J., Toledo J., Padilla A. M.: On the selection of the catalysts among the commercial platinum-based ones for total oxidation of some chlorinated hydrocarbons, Appl. Catal. B. Environ., 2000, 27, 243.

(7) Kaźmierczak M., Gorzka Z., Paryjczak T., Żarczyński A.: Treatment of toxic organic compounds occurring in industrial wastes with application of catalysts, Pol. J. Chem. Technol., 2002, 4, 8 .

(8) Kułażyński M., Van Ommen J. G., Trawczyński J., Walendziewski J.: Catalytic combustion of trichloroethylene over $\mathrm{TiO}_{2}-\mathrm{SiO}_{2}$ supported catalysts, Appl. Catal. B: Environmental, 2002, 36, 239.

(9) Żarczyński A., Gorzka Z., Paryjczak T., Kaźmierczak M., Szczepaniak B.: Dioxins in the process of 1,1,2,2-tetra- chloroethane oxidation with the application of monolithic catalysts, Pol. J. Chem. Tech., 2005, 7(2), 100.

(10) Żarczyński A., Kaźmierczak M., Gorzka Z., Zaborowski M.: Dioksyny w procesie utleniania 1,1,2,2-tetrachloroetanu w obecności wybranych katalizatorów. Chem. Inż. Ekol. 2005, 12(S1), 113.

(11) Koyer-Gołkowska A., Musialik-Piotrowska A., Rutkowski J.: Oxidation of chlorinated hydrocarbons over Pt-Rh-based catalyst. Part 1. Chlorinated methanes, Catal. Today, 2004, 90, 133.

(12) Finocchio E., Busca G., Notaro M.: A review of catalytic processes for the destruction of PCDD and PCDF from waste gases, Appl. Catal. B: Environmental, 2006, 62, 12.

(13) Żarczyński A., Gorzka Z., Paryjczak T., Zaborowski M., Kaźmierczak M.: Utylizacja tetrachloropochodnych z udziałem katalizatorów monolitycznych. Przem. Chem. 2006, 85 (8 - 9), 1095.

(14) Kaźmierczak M., Gorzka Z., Żarczyński A., Paryjczak T., Zaborowski M.: Activity of granular and monolithic catalysts during oxidation of selected organic chlorine compounds, Environmental Engineering, pp. 365 - 369, Taylor \& Francis Group, Londyn 2007.

(15) European Standard EN-1948, ICS 13.040.40 Stationary source emissions. Determination of the mass concentration of PCDD/Fs. Part 1. Sampling, Part 2. Extraction and clean-up, Part 3. Identification and Quantification.

(16) Rozporządzenie Ministra Środowiska z dn. 20. 12. 2005 r. w sprawie standardów emisyjnych z instalacji. Dz. U. 2005, nr 260, poz. 2181.

(17) Makles Z., Świątkowski A., Grybowska S.: Niebezpieczne dioksyny, Arkady, Warszawa, 2001. 